(a) OPEN ACCESS

${ }^{1}$ Internal Medicine, Dr Rajinder Prasad Government Medical College, Kangra, Himachal Pradesh, India

${ }^{2}$ Internal Medicine, Post Graduate Institute of Medical Education and Research, Chandigarh, India ${ }^{3}$ Internal Medicine, Army Hospital Research and Referral, New Delhi, Delhi, India ${ }^{4}$ Department of Radiotherapy and Oncology, IGMC, Shimla, Himachal Pradesh, India

\section{Correspondence to} Dr Kundan Mishra; mishrak20@gmail.com

Accepted 13 May 2021

\title{
Acute arthritis, skin rash and Lofgren's syndrome
}

\author{
Ajay Chauhan, ${ }^{1}$ Aditya Jandial (10, ${ }^{2}$ Kundan Mishra 다, ${ }^{3}$ Rajeev Sandal ${ }^{4}$
}

\section{SUMMARY}

Sarcoidosis is an autoimmune multisystem granulomatous disorder of unknown aetiology, which mainly affects the adults in the age group of 20-39 years. The disease can affect any organ in the body but mainly presents as bilateral hilar lymphadenopathy, pulmonary infiltrates, cutaneous lesions, ocular manifestations and arthropathy. Lofgren's syndrome is an uncommon initial presentation of sarcoidosis which is recognised by the classical triad of acute arthritis, erythema nodosum and bilateral hilar lymphadenopathy. We describe a newly diagnosed case of sarcoidosis who presented as Lofgren's syndrome. Acute sarcoid arthritis should be kept as one of the differential diagnoses for patients presenting with acute arthritis and skin lesions; and chest $X$-ray should be considered to rule out bilateral hilar lymphadenopathy in these patients. Early suspicion and identification of classical clinical features are essential to establish early diagnosis.

\section{BACKGROUND}

Sarcoidosis is a multisystem disorder which is characterised by hilar lymphadenopathy, pulmonary infiltrates, sarcoid arthropathy, cutaneous manifestations and ocular complications. It usually affects the young adults in the age group of 20-39 years. Long-standing joint involvement in sarcoidosis is seen in $10 \%-15 \%$ of patients; however, acute arthritis in sarcoidosis is mostly seen as part of Lofgren's syndrome. ${ }^{2}$ Seen in 5\%-10\% of sarcoid cases, Lofgren's syndrome is characterised by the classical triad of acute arthritis, erythema nodosum and hilar lymphadenopathy. ${ }^{3}$ We hereby describe the case of a 44-year-old woman with sarcoidosis who presented with Lofgren's syndrome. Prompt recognition of such classical clinical presentation of sarcoidosis leads to early diagnosis and treatment.

\section{CASE PRESENTATION}

A 44-year-old woman, with a known case of hypertension and hypothyroidism (on amlodipine $5 \mathrm{mg}$ daily and thryoxine replacement therapy), presented with fever, multiple joint pains and skin rash for 1-month duration. Joint pains were bilateral, symmetrical, inflammatory type mainly involving large joints (ankle, knee, elbow and wrist) with no history of morning stiffness, recurrent mouth ulcers, photophobia and Raynaud's phenomenon. On general physical examination, she had fever $\left(101^{\circ} \mathrm{F}\right)$ and tachycardia (126 beats/min) with no significant peripheral lymphadenopathy. She had multiple tender erythematous nodules on bilateral shins and forearms, suggestive of erythema nodosum (figure 1). On musculoskeletal examination, bilateral ankle and knee joints were swollen with erythematous overlying skin and tenderness (figure 2), suggestive of acute arthritis. Both passive and active movements were restricted in the affected joints. Examination of her chest, cardiovascular system and abdomen was unremarkable.

\section{INVESTIGATIONS}

On blood investigations, her haemoglobin was $100 \mathrm{~g} / \mathrm{L}$, total leucocyte count was $9 \times 10 \wedge 9 / \mathrm{L}$ and platelets were $250 \times 10 \wedge 9 / \mathrm{L}$. Her erythrocyte sedimentation rate and $C$ reactive protein were $38 \mathrm{~mm}$ at 1 hour and $69 \mathrm{mg} / \mathrm{L}(0.0-6.0 \mathrm{mg} / \mathrm{L})$, respectively. Her chest X-ray revealed bilateral hilar lymphadenopathy with normal lung parenchyma (figure 3 ). Her renal function tests, liver function tests, uric acid and calcium levels were within normal range. Her peripheral blood ACE level was elevated (143 U/L, normal range 12-68 U/L), and ELISA for antinuclear antibodies and tuberculin test were negative. Contrast-enhanced CT of the chest and abdomen showed bilateral hilar lymphadenopathy with no other abnormality. Punch biopsy from the cutaneous lesions revealed septal panniculitis. Transbronchial fine needle aspiration from the hilar lymph node was suggestive of non-caseating granulomas; GeneXpert and Ziehl-Neelsen stain for acidfast bacilli were negative. Her pulmonary function tests, blood culture and procalcitonin were normal.

\section{DIFFERENTIAL DIAGNOSIS}

On the basis of clinical picture, bilateral hilar lymphadenopathy and histological evidence of non-caseating granulomas, she was diagnosed with sarcoidosis with Lofgren's syndrome. Other differentials included extrapulmonary tuberculosis, septic arthritis, reactive arthritis and connective tissue disorders, for example, systemic lupus erythematosus and rheumatoid arthritis.

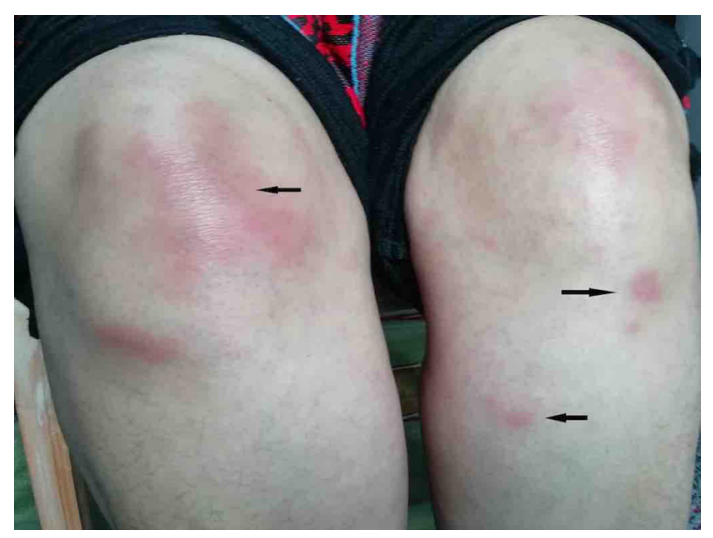

Figure 1 Clinical photograph shows erythematous, tender nodules on knee and shin (erythema nodosum). 


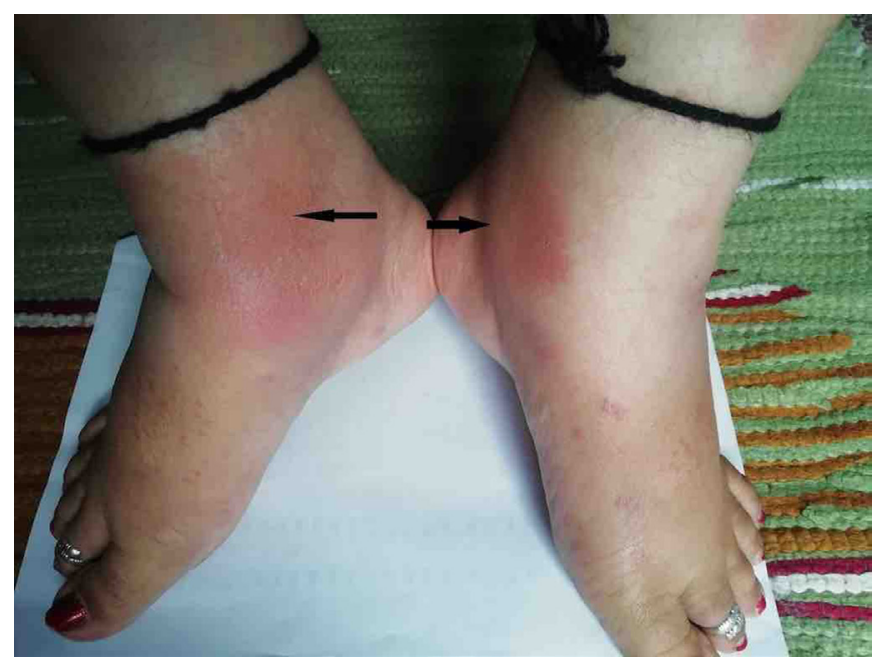

Figure 2 Bilateral ankle joint swelling and redness (acute sarcoid arthritis).

\section{TREATMENT}

She was started with oral naproxen $500 \mathrm{mg}$ three times per day, along with topical analgesics. She received naproxen for 1-week duration.

\section{OUTCOME AND FOLLOW-UP}

Her fever subsided after 2 days of treatment and joint pains improved over 2 weeks. At 6-month follow-up, her skin lesions had partially subsided. Further, her joint symptoms had fully recovered without therapy at 52-week follow-up. Her skin lesions had subsided and she also denied any pulmonary symptoms; however, repeat chest X-ray showed persistent hilar lymphadenopathy. She was advised regular follow-up.

\section{DISCUSSION}

Sarcoidosis is a multisystem granulomatous disorder of unknown aetiology. ${ }^{1}$ In India, the prevalence of sarcoidosis is not well known and it varies from 10-12 cases/1000 new registrations

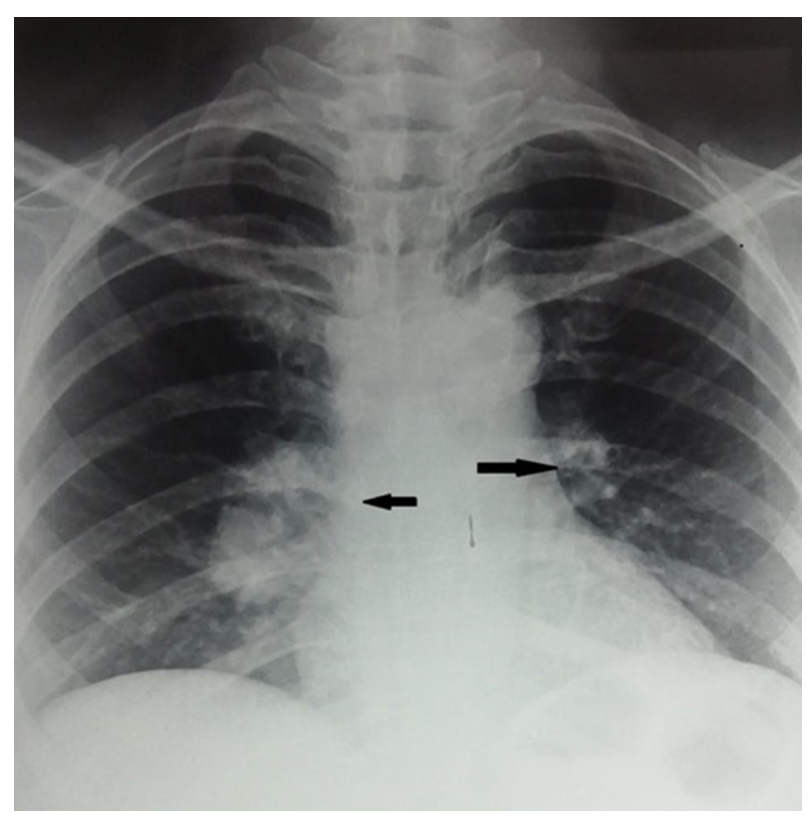

Figure 3 Chest X-ray showing bilateral hilar lymphadenopathy.

\section{Patient's perspective}

I was suffering from fever, joint pains and skin lesions for one month, when I came in contact with the treating team. I underwent multiple investigations which was quite anxietyprovoking for me. Then my treating team informed me that I am suffering from an uncommon disease known as sarcoidosis, and my symptoms are early features of my basic disease. They nicely explained me about the nature of the disease, its prognosis and future treatment plan. They advised me for regular follow up. I am very thankful to my treating team.

\section{Learning points}

- This case presented with the classical triad of Lofgren's syndrome, that is, acute arthritis, erythema nodosum and bilateral hilar lymphadenopathy.

- Acute sarcoid arthritis should be kept as differential of acute arthritis with skin lesions in young patients.

- Chest X-ray should be done to see hilar lymphadenopathy in young patients with arthritis.

- Strong clinical suspicion and prompt identification of classical clinical features can lead to early diagnosis and treatment.

to $61.2 / 100000$ as per the data reported by various centres across India. ${ }^{45}$ The disease can affect any organ in the body but mainly present as bilateral hilar lymphadenopathy, pulmonary infiltrates, cutaneous and joint lesions. ${ }^{16}$ It is pathologically diagnosed by the presence of sterile non-caseating granulomas in the involved organs. Lofgren's syndrome is a form of acute manifestation of sarcoidosis which is seen in 5\%-10\% of patients with sarcoidosis. It is a self-limiting clinical entity which is characterised by the triad of hilar lymphadenopathy, erythema nodosum and acute sarcoid arthritis. ${ }^{5}$ Fever is also associated with Lofgren's syndrome and seen mainly in women. Erythema nodosum is more common in women than men who present with Lofgren's syndrome. ${ }^{78}$ Elevated peripheral blood ACE levels are seen in approximately $15 \%$ of patients with initial presentation of Lofgren's syndrome, and these patients usually have persistent arthritis. ${ }^{9}$ Diagnosis of Lofgren's syndrome made on the basis of classical clinical manifestations and the diagnostic triad has 95\% specificity. ${ }^{10}$ Lofgren's syndrome is self-limiting and symptomatic treatment with non-steroidal anti-inflammatory drugs is adequate in almost all patients. Some patients may need additional therapy with corticosteroids. ${ }^{11}$ Therefore, acute sarcoid arthritis should be considered as one of the differential diagnoses for young patients with acute arthritis and rash. Chest X-ray to look for bilateral hilar lymphadenopathy can clinch the diagnosis of sarcoidosis in such patients.

Twitter Aditya Jandial @Aditya_PGI and Rajeev Sandal @rajeev_sandal

Contributors $\mathrm{AC}$-manuscript writing and patient management. AJ—manuscript editing and patient management. KM-manuscript supervision and patient management. RS — manuscript writing and patient management.

Funding The authors have not declared a specific grant for this research from any funding agency in the public, commercial or not-for-profit sectors.

Competing interests None declared.

Patient consent for publication Obtained.

Provenance and peer review Not commissioned; externally peer reviewed. 
Open access This is an open access article distributed in accordance with the Creative Commons Attribution Non Commercial (CC BY-NC 4.0) license, which permits others to distribute, remix, adapt, build upon this work non-commercially, and license their derivative works on different terms, provided the original work is properly cited and the use is non-commercial. See: http://creativecommons.org/ licenses/by-nc/4.0/.

\section{ORCID iDs}

Aditya Jandial http://orcid.org/0000-0002-6426-0309

Kundan Mishra http://orcid.org/0000-0001-5754-0946

\section{REFERENCES}

1 lannuzzi MC, Rybicki BA, Teirstein AS. Sarcoidosis. N Engl J Med 2007:357:2153-65.

2 Ungprasert P, Crowson CS, Matteson EL. Clinical characteristics of sarcoid arthropathy: a population-based study. Arthritis Care Res 2016;68:695-9.
3 Visser $\mathrm{H}$, Vos K, Zanelli E, et al. Sarcoid arthritis: clinical characteristics, diagnostic aspects, and risk factors. Ann Rheum Dis 2002;61:499-504.

4 Agarwal V, Agrawal V, Arthritis in Sarcoidosis Group (ASG), et al. Arthritis in sarcoidosis: a multicentric study from India. Int J Rheum Dis 2018:21:1728-33.

5 Jain R, Yadav D, Puranik N, et al. Sarcoidosis: causes, diagnosis, clinical features, and treatments. J Clin Med 2020:9:1081.

6 Bargagli E, Prasse A. Sarcoidosis: a review for the internist. Intern Emerg Med 2018:13:325-31.

7 O'Regan A, Berman JS. Sarcoidosis. Ann Intern Med 2012;156:ITC5. quiz ITC5-6.

8 Brown F, Modi P, Tanner LS. Lofgren syndrome. StatPearls. Treasure Island, FL: StatPearls Publishing Copyright (O), 2020.

9 Sejdic A, Graudal N, Baslund B. Clinical and biochemical presentation of sarcoidosis with high and normal serum angiotensin-converting enzyme. Scand I Rheumatol 2018;47:487-90.

10 Saltman AP, Kuriya B. Löfgren syndrome in acute sarcoidosis. CMAJ 2017:189:E1230.

11 Mañá J, Gómez-Vaquero C, Montero A, et al. Löfgren's syndrome revisited: a study of 186 patients. Am J Med 1999;107:240-5.

Copyright 2021 BMJ Publishing Group. All rights reserved. For permission to reuse any of this content visit https://www.bmj.com/company/products-services/rights-and-licensing/permissions/

BMJ Case Report Fellows may re-use this article for personal use and teaching without any further permission.

Become a Fellow of BMJ Case Reports today and you can:

- Submit as many cases as you like

- Enjoy fast sympathetic peer review and rapid publication of accepted articles

- Access all the published articles

- Re-use any of the published material for personal use and teaching without further permission

Customer Service

If you have any further queries about your subscription, please contact our customer services team on +44 (0) 2071111105 or via email at support@bmj.com. Visit casereports.bmj.com for more articles like this and to become a Fellow 